\title{
Blumea htamanthii (Asteraceae), a new species from Myanmar
}

\author{
Yulan Peng ${ }^{1,2}$, Chenxuan Yang 3 , Yan $\mathrm{Luo}^{3}$ \\ I Key Laboratory of Mountain Ecological Restoration and Bioresource Utilization \& Ecological Restoration \\ Biodiversity Conservation, China 2 Key Laboratory of Sichuan Province, Chengdu Institute of Biology, Chi- \\ nese Academy of Sciences, P.O. Box 416, Chengdu, Sichuan 610041, China 3 Gardening and Horticulture \\ Department, Xishuangbanna Tropical Botanical Garden, Chinese Academy of Sciences, Menglun, Mengla, \\ Yunnan 666303, China \\ Corresponding author: Yulan Peng (pengyl@cib.ac.cn)
}

Academic editor:Xiao-Hua Jin | Received 5 August 2019 | Accepted 11 September 2019 | Published 10 January 2020

Citation: Peng Y, Yang C, Luo Y (2020) Blumea htamanthii (Asteraceae), a new species from Myanmar. In: Jin X-H, Xia N-H, Tan Y-H (Eds) Plant diversity in Southeast Asia II. PhytoKeys 138: 225-232. https://doi.org/10.3897/phytokeys.138.38815

\begin{abstract}
A new species, Blumea htamanthii Y.L. Peng, C.X. Yang \& Y. Luo from Myanmar is described. The new species is distinguished from $B$. bifoliata by its leaves with short petioles, abaxially purple, leaf blade with papillary hair and sparse multicellular villous, capitula with 1-4 heads, glabrous florets and usually unbranched stems. A key to Blumea species in Myanmar is provided.
\end{abstract}

\section{Keywords}

Asteraceae, Blumea htamanthii, Myanmar, new species

\section{Introduction}

Blumea DC. is one of the largest and most taxonomically difficult genera in the Tribe Inulaceae, which includes approximately 100 species worldwide (Randeria 1960; Anderberg 1991, 1994, 2009; Pornpongrungrueng et al. 2016). Blumea is a monophyletic genus supported by molecular data (Pornpongrungrueng et al. 2007, 2009). Blumea is primarily distributed in tropical Asia, Africa and Oceania, while its highest diversity is in tropical Asia (Pornpongrungrueng et al. 2016). With the exception of the most common 
weeds in disturbed habitat, some species of Blumea have very narrow distribution areas at the edge of the forest. With the exception of partial revisions of 49 species of Blumea throughout the whole world by Randeria (1960) and of 27 species in continental Southeast Asia by Pornpongrungrueng et al. (2016), a whole revision of this genus worldwide is still lacking. Seventeen species were reported from Myanmar (Kress et al. 2003).

\section{Material and methods}

During our fieldwork in Myanmar in 2019, we found an undescribed species of Blumea. The plant that we collected in the Htamanthi Wildlife Reserve, Sagaing, is easily distinguished from any other taxa of Blumea by its specific flowers and leaves, i.e. its basal rosette abaxially purple leaves with papillary hairs and multicellular villous and $1-4$ capitula at the ends of the peduncles and unribbed achenes.

\section{Results}

\section{Blumea htamanthii Y.L.Peng, C.X.Yang \& Y.Luo, sp. nov.} urn:Isid:ipni.org:names:77204219-1

Figs $1-2$

Diagnosis. This new species is the most similar to Blumea bifolia (Linn.) DC. in its obovate-oblong leaves, reflexed linear phyllaries, flat, alveolate, glabrous receptacles. However, it is distinguished by its leaf blades with papillary hairs and sparse multicellular villous, abaxial purple, 1-4 capitula at the ends of the peduncles and its unribbed achenes.

Type. Myanmar: Htamanthi Wildlife Sanctuary, Hkamti District of Sagaing Region, the cliff near the edges of the forest along the branch river of Chindwin River, elevation $127 \mathrm{~m}, 25.4948593^{\circ} \mathrm{N}, 95.4319749^{\circ} \mathrm{E}$, May 23 2019,Y.L. Peng, C.X. Yang \& Y. Luo, SE02614 (Holotype CDBI!, Isotype HITBC!, RAF!).

Description. Annual herbs, herbaceous, 5-25 cm tall. Stems erect, occasionally procumbent, villous with multicellular hairs, leaves basal rosette or sub-basal rosette and a few cauline, petioles 0.2 to $0.3 \mathrm{~cm}$ long, at the base of petioles with white pilose hairs, lamina obovate or obovate-oblong, thinly papyraceous, $0.9-3.5 \times 0.3-1.2 \mathrm{~cm}$, acute at the apex, base abruptly constricted into winged petiole, margins distantly dentate, villous with multicellular hairs, both surfaces hairy, significantly discoloured, upper surface bright green, leaf blade with papillary hairs and sparse multicellular pilose, multicellular pilose on the veins are dense, lower surface purple, the base of margins serrate, apex acute; inflorescences loose panicles, $3-10 \mathrm{~cm}$ long, capitula terminal, rarely axillary, $1-4$ heads at the ends of the peduncles, 4-6 $\mathrm{mm}$ in diameter, peduncles $5-25 \mathrm{~mm}$ long with white pilose hairs; phyllaries herbaceous, slightly longer than the florets, $10-20 \mathrm{~mm}$ long, phyllaries in 5 (-6)-seriate, reflexed, outer phyllaries linear, with colleters and pilose hairs, lower part of the inner phyllaries lanceolate, upper part abruptly reduced to a linear tip, 

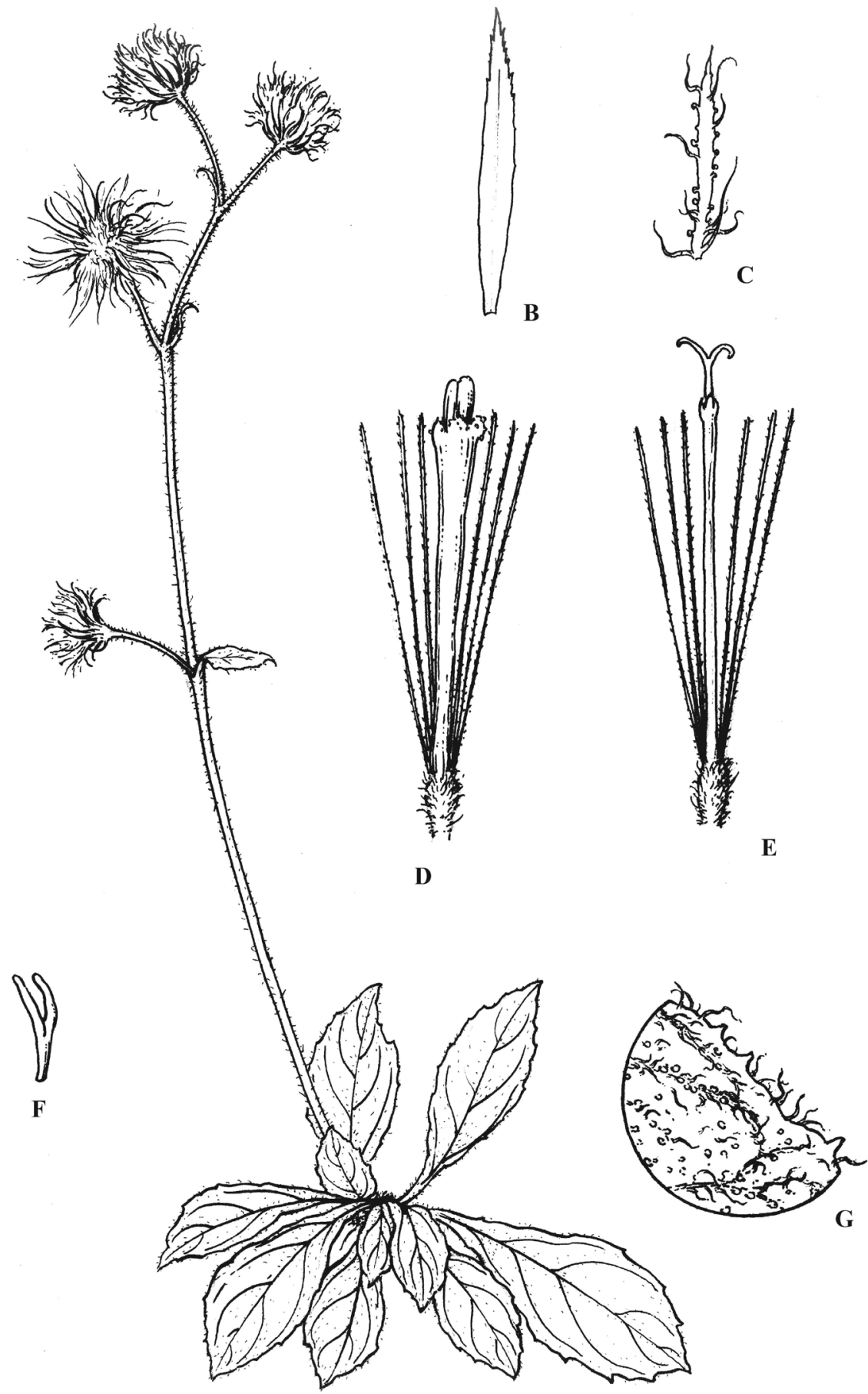

A

Figure I. Blumea htamanthii Y.L.Peng, C.X.Yang \& Y.Luo, sp. nov. A habit B the inner phyllary $\mathbf{C}$ the outer phyllary $\mathbf{D}$ bisexual floret $\mathbf{E}$ female floret $\mathbf{F}$ style of bisexual floret $\mathbf{G}$ magnified part of upper surface of the leaf. Drawings: Jian Gu based on the holotype. 

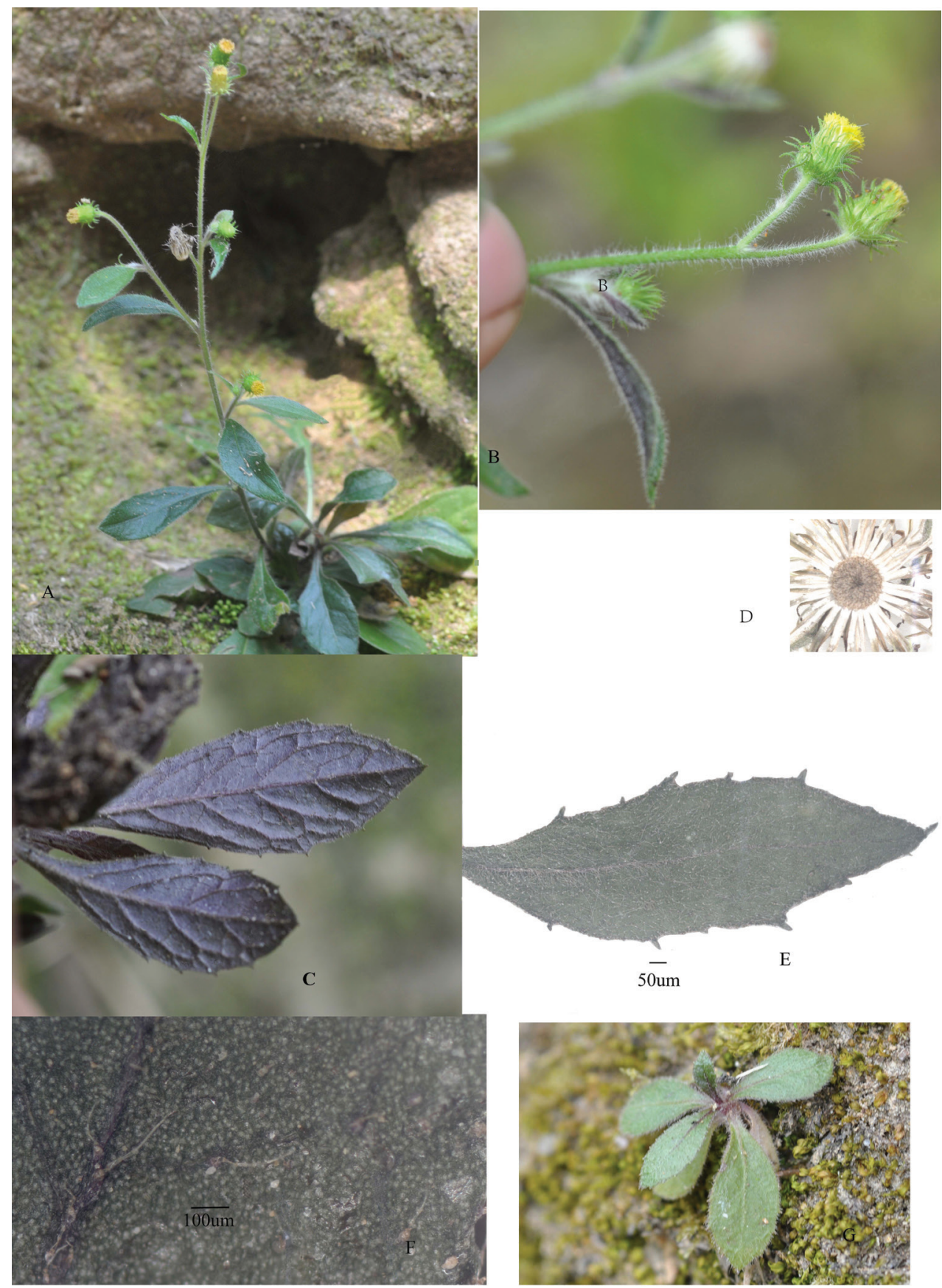

Figure 2. Blumea htamanthii Y.L.Peng, C.X.Yang \& Y.Luo, sp. nov. in the field and magnified leaves and receptacle $\mathbf{A}$ the whole plant $\mathbf{B}$ inflorescences $\mathbf{C}$ the abaxial surface of the leaf $\mathbf{D}$ receptacle $\mathbf{E}$ the upper surface of the leaf $\mathbf{F}$ magnified part of upper surface of the leaf $\mathbf{G}$ basal leaves. Photos: Y.L. Peng. 
the middle and upper part margin of the inner phyllaries lacerate, with sparse multicellular hairs, receptacle $0.5-1 \mathrm{~mm}$ in diameter, flat or slightly convex, alveolate, glabrous. Florets yellow, tubular, glabrous; those of the bisexual florets, corolla tube $3.5-4.5 \mathrm{~mm}$ long, with 5 ovate, papillate lobes, styles of the hermaphroditic flowers are wrapped in a slightly longer stamen tube; those of the female florets are filiform, up to $3.5 \mathrm{~mm}$ long, with 2 to 3 lobed, corolla tube $1-1.5 \mathrm{~mm}$ long. Cypselas pale brown, oblong, pubescent, not ribbed, 0.4-0.6 $\mathrm{mm}$ long, pilose; pappus carducous, white, 3-4 $\mathrm{mm}$ long.

Etymology. The new specific epithet "htamanthii" refers to the name of the town along the Chindwin River, Hkamti District of Sagaing, Myanmar, where the novel species was discovered.

Phenology. Flowering and fruiting April to June.

Distribution and habitat. Myanmar. Sagaing, Htamanthi; Blumea htamanthii is only known from the type collection along the branch river of Chindwin River, growing on the steep rocks near the forest from 66-366 m altitude above mean sea level, $25.4948^{\circ}-25.5152^{\circ} \mathrm{N}, 95.4319^{\circ}-95.5268^{\circ} \mathrm{E}$ in the Htamanthii Nature Reserve.

Additional material examined. $25.4947931^{\circ} \mathrm{N}, 95.4319147^{\circ} \mathrm{E}$, elevation $121-$ 129 m, 23 May 2019,Y.L Peng, C.X. Yang \&Y. Luo SE02645, SE02694 (CDBI, HITBC, RAF); 25.5132139 ${ }^{\circ} \mathrm{N}, 95.5269449^{\circ} \mathrm{E}$, elevation 36-367 m, 26 May 2019, Y.L. Peng, C.X. Yang \& Y. Luo SE02730, SE02731, SE02736 (CDBI, HITBC, RAF); 25.5127053N, 95.5267582 E, elevation 366 m, 27 May 2019, Y.L Peng, C.X.

Table I. A list of the morphological differences between Blumea tamanthii, B. bifoliata, B. diffusa and $B$. bicolor.

\begin{tabular}{|c|c|c|c|c|}
\hline Characters & Blumea btamanthii & Blumea bifoliata & Blumea diffusa & Blumea bicolor \\
\hline $\begin{array}{l}\text { Leaf } \\
\text { arrangement } \\
\text { patterns }\end{array}$ & $\begin{array}{l}\text { Basal rosette or sub-basal } \\
\text { rosette and a few cauline, the } \\
\text { cauline ones are all alternate }\end{array}$ & $\begin{array}{l}\text { Mostly cauline, the } \\
\text { uppermost pair are } \\
\text { subopposite }\end{array}$ & $\begin{array}{c}\text { Basal rosette or sub-basal } \\
\text { rosette and a few cauline; the } \\
\text { cauline ones are all alternate } \\
\text { and amplexicaulous }\end{array}$ & $\begin{array}{l}\text { The lower part of the stem } \\
\text { naked, leafless; the leaves } \\
\text { mostly aggregated in the } \\
\text { middle portion of the stem }\end{array}$ \\
\hline $\begin{array}{l}\text { Leaf } \\
\text { morphology }\end{array}$ & $\begin{array}{c}\text { Petioles } 0.2 \text { to } 0.3 \mathrm{~cm} \text { long, } \\
\text { lower surface purplish, apex } \\
\text { acute, leaf blade obovate } \\
\text { or obovate-oblong, villous } \\
\text { with papillary hair and } \\
\text { sparsely multicellular villous, } \\
0.9-3.5 \times 0.3-1.2 \mathrm{~cm}\end{array}$ & $\begin{array}{c}\text { Sessile, both surfaces green, } \\
\text { the apex acute or apiculate, } \\
\text { leaf blade oblong or ovate, } \\
\text { villous with multicellular } \\
\text { hairs and stipitate glands, } \\
\text { radical leaves } 0.7-3 \times \\
0.4-1.5 \mathrm{~cm}\end{array}$ & $\begin{array}{c}\text { Sessile, both surfaces } \\
\text { green, the apex acute to } \\
\text { apiculate, obovate or rarely } \\
\text { oblanceolate, pilose with } \\
\text { colleters and multicellular } \\
\text { hairs, } 2-6 \mathrm{~cm} \times 1.0-2.5 \\
\mathrm{~cm} \text { wide }\end{array}$ & $\begin{array}{l}\text { Lower surface purplish, } \\
\text { apex sharply acuminate, } \\
\text { blade oblong elliptic, } \\
\text { sparsely pilose with } \\
\text { multicellular hairs, } 5.5- \\
23.5 \times 1.3-8.6 \mathrm{~cm}\end{array}$ \\
\hline Stem & $\begin{array}{l}\text { Erect, occasionally } \\
\text { procumbent, usually } \\
\text { unbranched, pilose with } \\
\text { long, white hairs }\end{array}$ & $\begin{array}{l}\text { Erect, branched from the } \\
\text { base, ascending or rarely } \\
\text { procumbent }\end{array}$ & $\begin{array}{c}\text { Procumbent, stems branched } \\
\text { from the base, pilose with } \\
\text { long, white hairs }\end{array}$ & $\begin{array}{c}\text { Erect, generally } \\
\text { unbranched, puberulous }\end{array}$ \\
\hline Capitula & $\begin{array}{l}1-4 \text {, colleters and pilose } \\
\text { on the outer phyllaries, } \\
\text { the middle and upper } \\
\text { part margin of the inner } \\
\text { phyllaries lacerate }\end{array}$ & 1, glands on the phyllaries & 1 , pilose on the phyllaries & $\begin{array}{l}\text { Several formed a lax, } \\
\text { terminal panicle, pubescent } \\
\text { on the phyllaries }\end{array}$ \\
\hline Florets & Glabrous & $\begin{array}{c}\text { Sparsely pubescent on the } \\
\text { lobes }\end{array}$ & Glabrous & $\begin{array}{l}\text { Bisexual florets pubescent, } \\
\text { female florets glabrous }\end{array}$ \\
\hline Cypselas & Pilose, not ribbed & Pilose, 6-10-ribbed & Sparsely pilose, 10 -ribbed & Ribbed, pubescent \\
\hline
\end{tabular}


Yang \& Y. Luo, SE02769 (CDBI, HITBC, RAF); $25.5128305^{\circ} \mathrm{N}, 95.5268144^{\circ} \mathrm{E}$, elevation 366 m, 27 May 2019, SE02770 (CDBI, HITBC, RAF), 25.5133152 ${ }^{\circ} \mathrm{N}$, 95.5262927 ${ }^{\circ}$, elevation $340 \mathrm{~m}, 27$ May 2019, Y.L Peng, C.X. Yang \& Y. Luo SE02777 (CDBI, HITBC, RAF); 25.5128089² N, 95.5266037E, elevation $160 \mathrm{~m}, 27$ May 2019, Y.L Peng, C.X. Yang \& Y. Luo SE02806, SE02861(CDBI, HITBC, RAF).

Discussion. Blumea htamanthii resembles B. bifoliata (Linn.) DC. and B. diffusa R. Br. ex Benth. in its reflexed linear phyllaries, flat, alveolate, glabrous receptacle and obovate leaves. Blumea htamanthii differs from B. bifoliata by erect stem and basal bicolour rosette leaves, abaxially purple, with short petioles, leaf blade with papillary hairs and sparse multicellular villous and 1-4 capitula at the ends of the peduncles, achenes not ribbed (vs. leaves sessile, one colour, villous with multicellular hairs and stipitate glands, solitary capitula, achenes 6-10 ribbed) (Table 1). Blumea htamanthii differs from B. diffusa in erect stems and leaves with short petioles, cauline leaf base not amplexicaulous, and 1-4 capitula at the ends of the peduncles (vs. stems procumbent, leaves sessile, one colour, cauline amplexicaulous, solitary capitula) (Table 1). In addition, B. bicolor is endemic in the Philippines with abaxially purple leaves (Merrill 1912, Randeria 1960). However, it is a tall erect herb with leaves aggregated in the middle portion of the stem, leave blade oblong elliptic, $5.5-23.5 \times 1.3-8.6 \mathrm{~cm}$ and achenes ribbed. Its morphological traits are significantly different from those of B. htamanthii (Table 1).

Key to Blumea species in Myanmar (including the closely related species B. bicolor in the Philippines and B. diffusa in Australia)

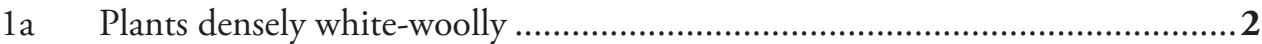

2a Outer phyllaries oblong-lanceolate, acute.........Blumea hieraciifolia (Don) DC.

2b Outer phyllaries linear and tapering .............................................................. 3

3a Capitula in large lax panicles; pappus red; corolla lobes of bisexual florets glabrous. Blumea densiflora DC.

3b Capitula in compact, spiciform panicles; pappus white; corolla lobes of bisexual florets hairy Blumea lacera (Burm. f.) DC.

$1 \mathrm{~b} \quad$ Plants glabrous or variously pubescent ……….......................................... 4

4a Phyllaries at least the outer phyllaries, oblong-ovate to oblong-lanceolate........5

5a Climber; receptacle densely pubescent; corolla lobes of female florets with multicellular hairs Blumea riparia (Blume) DC.

5b Erect, receptacle fimbrillate or rarely pilose; corolla lobes of female florets gla-

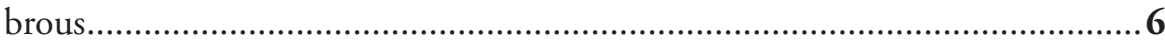

6a Receptacle fimbrillate or rarely pilose glabrous

Blumea lanceolaria (Roxb.) Druce

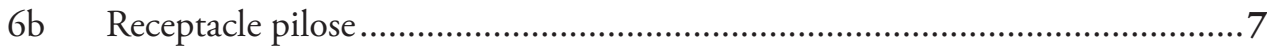

7a Capitula in narrow panicles................... Blumea hirsuta (Less.) M. R. Almeid

7b Capitula in large, spreading panicles........ Blumea repanda (Roxb.) Hand.-Mazz 
4b Phyllaries all linear or linear-lanceolate....................................................... 8

8a Receptacle fimibrillate.............................................. Blumea aromatica DC.

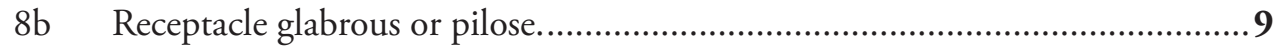

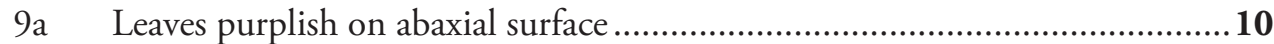

10a Height $20-100 \mathrm{~cm}$, the lower part of the stem naked, leafless, mostly aggregated in the middle portion of the stem

Blumea bicolor Merr

10b Height $5-25 \mathrm{~cm}$, leaves basal rosette or sub-basal rosette and a few cauline....... Blumea htamanthii Y.L.Peng, C.X.Yang \& Y.Luo, sp. nov.

9b Leaves not purplish on abaxial surface.......................................................11

11a Pappus reddish................................................ Blumea balsamifera (L.) DC.

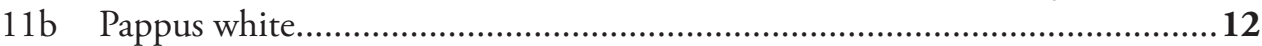

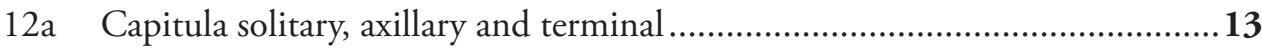

13a Diffuse herbs; leaves mostly radical, the cauline ones all alternate.

Blumea diffusa R. Br. ex Benth

13b Erect herbs; leaves mostly cauline, the uppermost pair subopposite. Blumea bifoliata (L.) DC.

12b Capitula interruptedly spiciform paniculate or loose or dense paniculate ........14

14a Inflorescence an interrupted spiciform panicle

Blumea fistulosa (Roxb.) Kurz

$14 \mathrm{~b}$ Inflorescence a loose or dense paniculate .....................................................15

15a Leaves spinous-toothed, stems procumbent.................. Blumea oxyodonta DC.

15b Leaves not spinous-toothed, stems erect.....................................................16

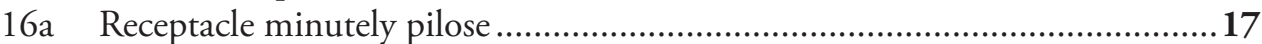

17a Leaves not lyrately lobed ...................................... Blumea adenophora Franch

17b Leaves lyrately lobed ...................................... Blumea sinulata (Lour.) Merr

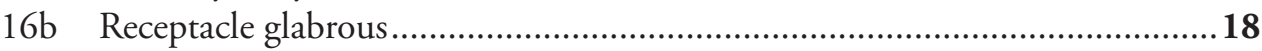

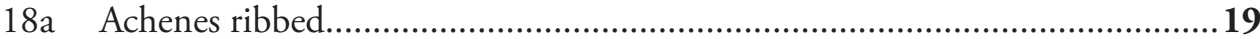

19a Plants more or less glabrate .................................. Blumea virens Wall. ex DC.

19b Plants pubescent or variously glandular......................... Blumea napifolia DC.

$18 \mathrm{~b}$ Achenes subangulate to terete ...................................................................20

20a Leaves usually not lobed; corollas purple............ Blumea axillaris (Lam.) DC.

20b Leaves often lyrately lobed; corollas yellow....... Blumea lacera (Burm. f.) DC.

\section{Acknowlegements}

We sincerely thank the staff of the Southeast Asia Biodiversity Research Institute, Chinese Academy of Sciences, for their help in the field. We are very grateful to Jian Gu for his drawings. We would like to thank the editors and reviewers for their comments. We also would like to thank the curators and staff of RAF and CDBI for their kindness and help. This work was supported by the Southeast Asia Biodiversity Research Institute, Chinese Academy of Sciences (Y4ZK111B01). 


\section{References}

Anderberg AA (1991) Taxonomy and phylogeny of the tribe Inuleae (Asteraceae). Plant Systematics and Evolution 176(1-2): 75-123. https://doi.org/10.1007/BF00937947

Anderberg AA (1994) Inuleae. In: Bremer K (Ed.) Asteraceae: Cladistics \& classification, Timber Press, Singapore, 273-291.

Anderberg AA (2009) Inuleae. In: Funk VA, Susanna A, Stuessy TF, Bayer RJ (Eds) Systematics, evolution, and biogeography of Compositae. IAPT, Vienna, 667-680.

Anderberg AA, Eldenäs P (2007) XVII. Tribe Inuleae Cass. In: Kadereit JW, Jeffrey C (Eds) The families and genera of vascular plants. [Vol. 8.] Flowering plants- eudicot, Asterales, Springer, Berlin, 374-390.

Kress WJ, De Filipps A, Farr E, Kyi DYY (2003) A checklist of the trees, shrubs, herbs, and climbers of Myanmar. Contributions from the United States National Herbarium 45: 1-590. https://doi.org/10.1600/036364404774195674

Merrill ED (1912) New or Noteworthy Philippine Plants, IX. The Philippine Journal of Sciences (Section C, Botany) 7: 259-357.

Pornpongrungrueng P, Borchsenius F, Englund M, Anderberg AA, Gustafsson MHG (2007) Phylogenetic relationships in Blumea (Asteraceae: Inuleae) as evidenced by molecular and morphological data. Plant Systematics and Evolution 269: 223-243. https://doi. org/10.1007/s00606-007-0581-7

Pornpongrungrueng P, Borchsenius F, Gustafsson MHG (2009) Relationships within Blumea (Inuleae, Asteraceae) and the utility of the 5S-NTS in species-level phylogeny reconstruction. Taxon 58(4): 1181-1193. https://doi.org/10.1002/tax.584011

Pornpongrungrueng P, Gustafsson MHG, Borchsenius F, Koyama H, Chantaranothai P (2016) Blumea (Compositae: Inuleae) in continental Southeast Asia. Kew Bulletin 71: 1-46. https://doi.org/10.1007/s12225-016-9612-2

Randeria AJ (1960) The Compositae genus Blumea: A taxonomic revision. Blumea 10: 176-317. 